\title{
Civilisations
}

Revue internationale d'anthropologie et de sciences

humaines

$60-2 \mid 2012$

Être ou ne pas être balkanique

\section{Transylvanian Saxon Symbolic Geographies}

\section{Cristian Cercel}

\section{OpenEdition}

\section{Journals}

\section{Electronic version}

URL: http://journals.openedition.org/civilisations/3019

DOI: 10.4000/civilisations.3019

ISSN: 2032-0442

\section{Publisher}

Institut de sociologie de l'Université Libre de Bruxelles

\section{Printed version}

Date of publication: 27 July 2012

Number of pages: 83-101

ISSN: 0009-8140

\section{Electronic reference}

Cristian Cercel, «Transylvanian Saxon Symbolic Geographies », Civilisations [Online], 60-2 | 2012,

Online since 30 August 2015, connection on 12 November 2019. URL : http://journals.openedition.org/ civilisations/3019; DOI : 10.4000/civilisations.3019

(c) Tous droits réservés 


\title{
Transylvanian Saxon Symbolic Geographies
}

\author{
Cristian CERCEL
}

\begin{abstract}
In Transylvanian Saxon self-identification, representations of the Balkans as the uncivilized region lying on the other side of the Carpathians have constantly circulated, among other things via literary products. The perception of Saxonness as embodiment of a higher culture and symbol of civilization has been accompanied by a perception of the Romanian/ Wallachian other as Balkanic, hence backward and uncivilized. Placing these considerations within a broader theoretical setting, one could speak of orientalizing representations, or of a specific case of a 'nesting orientalism'. However, after 1918 Transylvania and the lands beyond the Carpathians had become part of the same state. In this context, this paper intends to investigate how were the Balkans perceived within relevant post-1918 Transylvanian Saxon literary products, from Meschendörfer to Schlattner, and what have been the key features of the Transylvanian Saxon relationship with this world to which they did not want to belong, yet with which they were bound to interact.
\end{abstract}

Keywords: identification discourses, symbolic geographies, Transylvanian Saxons, Romania, Balkans.

Résumé : Dans la compréhension de soi saxonne de Transylvanie, des représentations des Balkans comme région non civilisée s'étendant de l'autre côté des Carpates ont circulé depuis longtemps, notamment au travers de productions littéraires. La perception de l'identité saxonne comme l'incarnation d'une culture supérieure et un symbole de civilisation est allée de pair avec une perception de l'Autre roumain ou valache comme 'balkanique', c'est-à-dire arriéré et non civilisé. En replaçant ces considérations dans un cadre théorique plus large, on pourrait parler de représentations orientalisantes, ou d'un cas spécifique d'orientalisme enchâssé'. Après 1918 toutefois, la Transylvanie et les territoires situés au-delà des Carpates furent réunis en un même Etat. Dans ce contexte, cet article s'interroge sur la façon dont les Balkans furent perçus dans la littérature saxonne transylvaine pertinente d'après 1918, de Meschendörfer à Schlattner, et sur les dimensions essentielles de la relation saxonne transylvaine à ce monde auquel les Saxons ne voulaient pas appartenir, mais avec lequel ils étaient désormais liés.

Mots clefs : discours identitaires, geographies symboliques, Saxons transylvains, Roumanie, Balkans. 


\section{Introduction}

Lying at the 'crossroads of empires' and peripherically related to several political and cultural centers, a typical feature of ethnic groups living in the shifting CentralEastern part of the European continent, Transylvanian Saxons produced various identification discourses in the course of history. This article looks at Transylvanian Saxon self-identification from 1918 onwards, focusing on the related symbolic geographies and on the East-West divide this identification has been recurrently connected with, albeit in different ways. Its main sources are literary products, showing how mutations in Transylvanian Saxon identification discourses are mirrored therein.

\section{Transylvanian Saxons in Historical and Cultural Context}

In the $12^{\text {th }}$ century, at the behest of the Magyar King Géza II, settlers from different German-speaking regions, such as the Mosel region, Flanders and Luxembourg were invited to Transylvania in order to colonize the presumably deserted territory newly conquered by the Hungarian Crown. Their migration to Eastern Europe is historically part of the so-called Deutsche Ostsiedlung, German colonization towards East (Nägler 1992; Higounet 1989), a quintessential process in view of the subsequent shaping of German identity in the Central and Eastern parts of the European continent.

Transylvanian Saxons were therefore colonizers in a presumably scarcely populated region: their being invited in the 'land beyond the forests' was meant on the one hand to support its economic enhancement and consequently that of the Hungarian kingdom and on the other hand to defend the latter's physical borders, on the Carpathian Mountains. ${ }^{1}$ German-speaking people settled then for military and economic purposes. Moreover, the colonists were enticed through the granting of an autonomy status in a clearly delimited region, the so-called Königsboden (Crown Lands). The autonomy regarded administrative, jurisdictional and cultural-religious matters. These privileges were managed and implemented by an institution called the Nationsuniversität (Universitas Saxonum/Saxon University), whose leader was the Saxon Komes (Count).

In time, mostly on the basis of this autonomous status within the Transylvanian region, the group developed a specific self-consciousness, as the settlers and their descendants perceived themselves and were perceived by external observers as saxones (Transylvanian Saxons). Konrad Gündisch (1998: 89-91) argued that a distinct Transylvanian Saxon group identity emerged from the $16^{\text {th }}$ century onwards, under the influence of the cultural elite, and mainly on the basis of the autonomous jurisdictional system. Considering the outstanding success of the Reformation amongst the Saxons in Transylvania and the consequential de facto equivalence between Lutheran and Saxon in the region, the religious denomination also developed

1. In the case of Burzenland (Țara Bârsei), border region between the Hungarian kingdom and the principality of Wallachia, the latter under Ottoman dominance until 1877, the first colonizing initiative of the Hungarian Crown attracted the Teutonic Knights some decades before the arrival of the Transylvanian Saxons. The Teutonic Knights eventually left the region following conflicts with Hungarian central authorities (Zimmermann 2000). 
as a key indicator of identity, the Lutheran Church being a Volkskirche, that is a "national church" (Zach 1998).

At the same time, it ought to be emphasized that nourishing constant cultural relationships with the German linguistic space was another key element for Transylvanian Saxon identification, contributing to the emergence and stabilization of what Glynn Custred (1991) called the "dual ethnic identity of the Transylvanian Saxons." A symbol of this connection with the German cultural space has been their being named in the $17^{\text {th }}$ century germanissimi germanorum, the most German of all Germans (Neubauer and Cornis-Pope 2006: 250; Evans 2006: 221), a remark that would be later used and reused in order to convey a feeling of superiority and to mould a specific type of German identification in Transylvania, with long-term consequences.

The advent of Enlightenment and modernity brought forth significant changes in the institutional life of the Transylvanian Saxons. Following the Josephinian reforms of late $18^{\text {th }}$ century and the imposition of the Austro-Hungarian Dualism in 1867 , Transylvanian Saxons lost the greatest part of their traditional autonomy, their status being in practice downgraded to that of an ethnic minority in the Hungarian part of the Habsburg Empire. Subsequently, the Habsburg Emperor Joseph II allowed members of other ethnic groups to settle on Saxon lands, enjoying full equality (Roth 1996: 86). According to Paul Philippi (1994: 69), this event represents the beginning of modern history for the Transylvanian Saxons, since it put an end to the medieval privileges assigned to them centuries before, privileges that had constituted the crux of Saxon identification. Later on, from 1867 onwards, the community and its members found themselves under heavy Magyarization pressures. Disappointed by the central authorities in Vienna and at the same time perked up by the military and political successes of Bismarck's Germany, a significant part of the Transylvanian Saxon elites started to be more influenced by the latter in both cultural and political issues. At the same time, in this period salient conflicts appeared amongst the community elites, fundamentally dealing with issues related to Transylvanian Saxon self-identification and self-consciousness (Möckel 1994).

Following the First World War and the disbandment of the Habsburg Empire, Transylvania was incorporated into the young Romanian state, officially founded in 1859. Although acquiesced in by the Transylvanian Saxon community through its representatives gathered in Mediasch (Mediaş), the transition to Romania was received in practice with unease and sceptical enthusiasm. The promises inserted into the Romanian Declaration of Alba Iulia of 1918, and into the Paris Peace Treaties of 1919, included jurisdictional and educational autonomy for the Transylvanian Saxons. ${ }^{2}$ Nonetheless, central authorities in Bucharest subsequently forbore from fulfilling the aforementioned promises, being tributary to nation-building aims and goals and to a lack of experience in dealing with ethnic minorities (Livezeanu 1995).

2. See "Rezoluțiunea Adunării Naționale de la Alba Iulia din 18 Noiembrie/1 Decembrie 1918", available at http://www.cimec.ro/Istorie/Unire/alba.htm (last accessed, 20 December 2010) and "Treaty between the Principal Allied and Associated Powers and Roumania, signed at Paris, December 9, 1919 [1921]", available at http://www.worldlii.org/int/other/LNTSer/1921/63.html (last accessed, 20 December 2010). 
The new political environment implied the transformation of the Romanians from a minority deprived of rights in the Hungarian part of the Habsburg Empire, to a population enjoying the status of a state-bearing nation in Transylvania. In other words, from being politically subordinate to having political leverage upon the other ethnic groups now living in the country. On the basis of widespread views of the Romanian state as part of the Balkans and of the latter's cultural indebtedness to Ottoman institutions and mores, Saxons feared the potential future 'Balkanization' of Transylvania, i.e. the harmonization of political and social relationships in the region with the ones on the other side of the Carpathians, according to the pattern of the latter (Gündisch 1998: 173; Davis 2011).

It can be argued that the Transylvanian Saxon view of Romanians and of the Romanian state on the other side of the Carpathians displays a series of similarities with a wider cultural German view of the East. Vejas Gabriel Liulevicius (2009: 48) analyzed what he called a German "myth" of the East emerging at the beginning of the $19^{\text {th }}$ century. He pointed out its main themes: "an intrinsic eastern disorder, disease, dirt, a deep incapacity for self-rule, which was expressed in the allied phenomena of despotism and slavery; sympathetic encounters; and the assertion of a particular German national calling or mission." More recently, David Hamlin investigated the discursive constructions of the German "encounter" with Romania and with Romanians during the First World War, underlining the 'Euro-Orientalist' frame of reference most suitable for comprehending these constructions (Hamlin 2010; for the concept of 'Euro-Orientalism', see Adamovsky 2005).

Although essentially seen from the outside as Auslandsdeutsche (Germans from abroad), i.e. not fully within but also definitely not outside German culture, the constant rapprochement of Saxons towards the German cultural space and, from the end of the $19^{\text {th }}$ century onwards, towards the German state as such, went hand in hand with a specific self-image, whose main traits were connected with the civilizing role ("calling or mission") of the Transylvanian Saxons in Eastern Europe. As a consequence of this perceived role, Transylvanian Saxon values and identity discourses were forged in accordance to 'Western' values and identities (Roth 1998). Furthermore, in direct relationship with this specific self-view, it can be sustained that Transylvanian Saxons tended to adopt a mixture of condescending and empathetic views in their perception of Romanians and Romanian institutions, especially of the ones on the other side of the Carpathians.

By means of these observations, I do not wish to convey the image of a single, reified 'Transylvanian Saxon perspective' on Romanianness and/or on the Eastern parts of Europe, thus toning down or underestimating the various opinions within the community. Nonetheless, referring to the Transylvanian Saxon community after 1918, the predominance of ethnicized lenses used to understand and explain the world should under no circumstances be dismissed. My subsequent analysis will refer to works where an ethnicized understanding of the world is almost a priori presumed and where identity discourses referring to 'Saxons' or 'Romanians' are rather the rule than the exception.

In order to stress out the common Transylvanian Saxon self-view, nourished by the elite, and the associated colonizing condescending Transylvanian Saxon view of 
Romanians and of the Balkans/Orient, ${ }^{3}$ one can recur to some meaningful modern Transylvanian Saxon historiographical products. A sterling example contributing to understanding the way Romanian-Saxon relationships were traditionally perceived within the Saxon community is given by Friedrich Teutsch, historian and Bishop of the Lutheran Church. In 1916, he published the first edition of a work called Die Siebenbürger Sachsen in Vergangenheit und Gegenwart, aimed at a German (Binnendeutsch) readership. Starting from his foreword, he did not fail to punctuate the positive Transylvanian Saxon self-stereotypes: a "people of colonists", "conveyer of high culture" and "educator of the environment", compelled to cope with the difficulties implied by the harsh and unfriendly ambience (Teutsch 1916: IX-XI). Analyzing Teutsch's writing in depth would unnecessarily go beyond the scope of this paper, yet referring to his work is cardinal for understanding the cultural jerk implied by Transylvania's annexation of Romania in Transylvanian Saxon view and hence for my subsequent exposé.

The history of the German-speaking group in Transylvania is predominantly presented as a history under the threat of the Turkish/Ottoman danger coming from the Orient: "They could not recognize the dual danger, that would be coming from the Orient in those times: to begin with, the Romanians (Walachians) settling down at the borders of the Saxon region, against whose unculture Saxons first defended themselves with fire and sword; and the Turks, who would be a scourge for the country for three hundred years" (Teutsch 1916: 35). ${ }^{4}$ Most interestingly, in the second, augmented edition of the work, published in 1924, Teutsch (1924: 34) eliminated the word "unculture" (Unkultur), replacing it with "attacks" (Angriffe), a sign of political calculation, probably meant to appease the sensibilities of the new state-bearing nation.

Moving closer to the time when he was writing the piece, the Bishop-historian recognized the danger implied by the high birth rate and the migration of the Romanian population to Transylvanian Saxon localities, in the detriment of the Transylvanian Saxon population (Teutsch 1916: 296-297). The former subjects, representatives of an uncultured population, yet ungrateful pupils of the Transylvanian Saxon instructorship, were starting to saliently outnumber the descendants of the former colonists, a phenomenon fretfully taken into consideration by Saxon elites.

\section{Research Question}

Considering this historical and cultural context, the present paper deals with the moment of crisis associated with Transylvania's incorporation into Romania and with its consequences upon Transylvanian Saxon identification, as mirrored in certain literary products engaging, directly or indirectly, with the topic. According to Peter

3. I use the two categories as being rather synonymous. The Balkans and the Ottoman Empire are present in Saxon historiography; so are the Mongols, due to the Mongol Invasion of Transylvania, which strongly affected Transylvanian Saxon development. Whatever lies on the other side of the Carpathians is usually associated with threat and peril, or with lack of order and discipline, without meaningful distinctions between Balkan and Orient.

4. All the translations from German or Romanian into English were made by the author of this article. 
Motzan (1997: 74), the 'auslandsdeutsche' literature is an adequate field of exercise for interdisciplinary methods. I am openly eschewing myself from deliberating on the aesthetic or literary value of the works under scrutiny. I am in effect looking only at their representations of Transylvanian Saxon identity and, more precisely, of Transylvanian Saxon symbolic geographies and symbolic boundaries with respect to the other ethnic groups living in the region and in the broader Romanian state.

There is a plethoric body of Transylvanian Saxon literature. This complicates the task of selecting the most appropriate products to look at and irrefutably transforms the process of selection into one bound to create a discourse in its own turn. I am totally aware of the high degree of subjectivity implied by such a selection made by an outsider to literary criticism. I chose four novels written by four different authors: Adolf Meschendörfer, Heinrich Zillich, Georg Scherg and Eginald Schlattner. The selection implies that other important Transylvanian Saxon writers, such as Joachim Wittstock, Erwin Wittstock, Hans Bergel, Paul Schuster or Andreas Birkner, Dieter Schlesak (among others) are left aside. Their work would constitute excellent material for any research on discourses about Transylvanian Saxon identity, yet constantly enlarging the pool of authors to be taken into consideration for this investigation would have been a self-defeating endeavour, so at one point halt had to be put.

In this context, the reasons for inclusion are more important than the ones for exclusion. I have included two of the most important writings: Die Stadt im Osten (The Town in the East) by Meschendörfer and Zillich's Zwischen Grenzen und Zeiten (Between Borders and Eras). By 'important' I mostly refer to the attention granted to them beyond Transylvania, more precisely in Nazi Germany (Sienerth 2003). Scherg's Da keiner Herr und keiner Knecht (No Master and No Servant), published under Communism, has been chosen on behalf of its symbolic relevance, visible even from the title, for Transylvanian Saxon identity. As Olivia Spiridon $(2002,91)$ notes, the novel is a critique of Transylvanian Saxon society. Last, but not least, Schlattner's Der geköpfte Hahn (The Beheaded Rooster), published after the fall of Communism, also deals with the interwar period and is an excellent example of a cultural memory product, shaping memory and at the same time discoursing identity (Cercel 2011: 173). A similar argument can be made with respect with Das Klavier im Nebel (The Piano in the Fog), Schlattner's most recent novel.

\section{Theoretical Framework}

Through Transylvania's incorporation into Romania, which took place in 1918, Transylvanian Saxons were compelled to accept not only the political presence, but also the political superiority of the neighboring 'other', more Eastern and more Oriental par excellence. What this paper aims to show, by referring mainly to the four epitomic literary products listed above, is that against the background of shifting political frontiers in the past century, Transylvanian Saxon symbolic geographies were also prone to suffer changes and mutations.

Analyzing representations of otherness in the former Yugoslav space, Milica Bakić-Hayden (1995) explicated a phenomenon she called 'nesting orientalisms', i.e. a gradation of 'Orients' in the South-East European space, according to which the East-West dichotomy is reproduced within Eastern Europe and the Balkans (also 
Bakić-Hayden and Hayden 1992). More precisely, this dichotomy is used to ascribe 'Balkan' or 'Oriental' traits and features to the more Eastern other, thus creating a 'Western' self-identification for one's own group (Bakić-Hayden and Hayden 1992; Bakić-Hayden 1995; Bjelić,2002: 4). Analyzing Romanian symbolic geographies, Sorin Antohi spoke about the "metonymic character" of this penchant to marginalize otherness. According to him, the reasons for the stigma associated with Romanianness are always to be blamed on the other regions, most usually those more to the South or more to the East (Antohi 1999: 244 et passim).

By using and adjusting these and alike considerations, this paper shows that internal Transylvanian Saxon identification, tightly linked with the question of where do the Balkans start, has been a sterling example of a 'nesting orientalism', the West-East binary being reproduced in general lines through various identification discourses. Furthermore, it contends that Transylvanian Saxon cultural and political integration into the Romanian state brought forth on the long term a subtle redefinition of identities and hence of symbolic group boundaries and of the relationship with the Romanian population. This redefinition is visible by recurring to a comparative reading of the aforementioned novels.

Expressing it in more straightforward words: what I illustrate is that Transylvanian Saxon identification discourses in Romania moved from a fiery-proud 'Western bulwark' type of discourse to a more nuanced one, in which Transylvanian Saxons are seen as simultaneously belonging and not belonging to the East, a bridge between cultures. The paradoxes derived thereof are best understood in relationship to the tensions specific to Transylvanian Saxon identification discourses in the past century. Consequently, the present article shows how identity discourses changed and symbolic geographies shifted according to the political situation of the Transylvanian Saxons and to the context in which the literary pieces under scrutiny have been written.

\section{Transylvanian Saxon Symbolic Geographies}

\section{Kronstadt and the Black Church}

In an ideal Transylvanian Saxon symbolic geography, the Black Church in Kronstadt (Braşov) could mark the end of the civilized world. On the other side are the Balkans, or, in a more nuancé and less straightforward tonality, another world and another type of mentality. Not by chance, in the texts I have chosen for my analysis, Kronstadt and the wider geographical subregion it is part of, Burzenland, play a key role. Burzenland used to lie at the political frontier of the Habsburg Empire and the Romanian state before 1918, a frontier erased through the Peace Treaties following the First World War. After 1918, following border changes, Burzenland would find itself lying in the centre of Romania. Its strategic importance for the identity management of Transylvanian Saxons has come in the course of history first and foremost from its location, at the frontier of both Transylvania and, internally, of the Königsboden, the region and the town of Kronstadt being from the $18^{\text {th }}$ century onwards extremely penetrable through Romanian demographic advancement. Consequently, its presence in a number of key volumes within Transylvanian Saxon literature is not a random 
event, but underlines its significance for the community, and transforms it into a place where identities are symbolically invested, but also contended against.

Following the First World War, a new geographical positioning of Burzenland was produced, also resulting in a new type of symbolical positioning. The shift in the political frontier did not necessarily annul the perceived existence of a cultural boundary. Sorin Mitu (2007: 64) summarized the signification of the change of power in Transylvania: "After 1918, through its integration into the Romanian kingdom, inhabited by orthodox in its majority, Transylvania was administratively moved from one region to another: from Vienna-oriented Central Europe, it swayed towards an Eastern Europe navigating in the backwash of Moscow and towards the Balkans impregnated by the Oriental dilatoriness of Istanbul". Using such socio-cultural divisions as analytical instruments is in many ways fallacious, yet the present article considers first and foremost their discursive nature and henceforth looks rather at how such divisions are discursively produced, without arguing on behalf of their truthfulness as social, cultural or political facts.

Kronstadt, the capital of Burzenland and one of the two major economic and cultural hubs for Transylvanian Saxons, next to Hermannstadt (Sibiu), has a twofold symbolic significance for the Transylvanian Saxon community. On the one hand, this has been attributable to its position as a stronghold, in the proximity of the frontier with the Ottoman Empire. ${ }^{5}$ On the other hand, this relevance is due to the presence in the town of the Black Church, the biggest Gothic edifice in South-East Europe, an identification marker for Saxon self-consciousness and self-representation (Motzan 2001: 55).

The Church per se is often an "object" in Transylvanian Saxon literature, as Motzan noted. Its being Lutheran reminds one of Transylvania's plurireligious character, but also of the hierarchy revealed by religion within specific European symbolic geographies (Bakić-Hayden and Hayden 1992: 4). It appears in all four novels set at one point or another in Kronstadt. In Zillich's Zwischen Grenzen und Zeiten, the reader is plunged abruptly in the Transylvanian bucolic atmosphere by means of a depiction of the bells tolling in the entire Burzenland, on Sunday morning (Zillich 1937: 7). The depiction reaches its climax when Zillich refers to the Black Church and to "the big bell from Kronstadt", heard in its entire force: "It does not toll every Sunday. But when it does, it is as if the mountain itself opened its heart there, where the Carpathians formidably climb up in the blue" (Zillich 1937: 8). Adolf Meschendörfer, in his Die Stadt im Osten, also came up with a majestic account of the sound of the Black Church bell: "On a Friday afternoon, around 4, the big bell started to chime. Its noble voice resounded from the near tower; the powerful sound waves were rattling around the windowpanes" (Meschendörfer 1931: 93). Scherg referred to the Black Church and to its bell, "tolling all the way up to the mountains and far away in the country" (Scherg 1966: 198).

The Black Church plays a symbolic part in Schlattner's novel as well: the grandfather of the narrator considers that Europe ends with the Black Church:

5. Stricto sensu, the frontier separated Transylvania from Wallachia, a principality under the suzerainty of the Ottoman Empire. 
"The Balkans begin on the other side of the Carpathians, another, strange world" (Schlattner 2009: 498). The consequence is transparent, as it conveys the message of the Transylvanian Saxons as defenders of Europe's borders, and at the same time marking the Europeanness of the border territory through their architectural feats. However, when Felix Goldschmidt, the main character of Schlattner's novel is telling this Balkans' definition to his Romanian girlfriend, she retorts with her grandmother's demarcation of the Balkans, according to which they start on the other side of the Danube (Schlattner 2009: 498). Europeanness becomes therefore a counterpart to Balkanness, with representatives of each group stating not only their belonging to Europe, but also their being situated on the European frontier, thus marking it. However, the grandfather's assertions go on: the Balkans stand for an attitude and a way of life, sometimes existing in Transylvania as well, yet implicitly opposed to Saxonness. This leads to another quintessential feature of Transylvanian Saxon identity: they are to be perceived as educators and instructors, agents of civilization and of Europeanness in a Balkanness-imbued environment.

\section{The Carpathian Mountains as natural borders}

Significantly, Burzenland is a region surrounded by mountains, more precisely by the Carpathians. Scherg emphasized it in his novel, whilst Zillich (1937: 110) also granted importance to the mountainous chain almost encircling Kronstadt. For Meschendörfer, these natural resources were cardinal in shaping Transylvanian Saxon identity: the mountains act as natural borders meant to be defended, as they are surrounding the town. However, this encirclement is also a way of trapping the town's inhabitants. If the mountain is perceived as a "fateful mountain" for the Saxons of Kronstadt, it also has the ability of transforming the town in a "mouse-trap with one exit in the plain" (Meschendörfer 1931: 16). One could even speak of a cultural penchant toward mountains and their relevance for group identity, specific to the Transylvanian Saxon community, especially from the end of the $19^{\text {th }}$ century onwards: the foundation and the ongoing activity of the Siebenbürgischer Karpatenverein stands proof for that (Wedekind 2004), together with the attempts to keep its German character up to recent times (Grama-Neamțu 2010). In Das Klavier im Nebel (The Piano in the Fog), the last novel from Schlattner's trilogy, the Romanian character, Rodica, states with reference to Transylvanian Saxons: "For you, Saxons, the mountains are sacred." (Schlattner 2007: 326).

Paradoxically, Transylvania's incorporation into Romania led to the transformation of a natural frontier - the Carpathian Mountains - into an integrative natural element. What used to divide was now bound to unite the Romanians living on both sides of the mountainous chain. Lucian Boia (2001: 59) commented upon the symbolic role of the Carpathians in the narrative of Romanian unity along centuries. In a variety of Romanian historiographic discourses indeed, the separating mountainous chain becomes a uniting one. Yet for Transylvanian Saxons, the Carpathians rather had another function, as they constituted the natural frontier separating West and East, Europe and the Balkans. 
Space, territory, cultural and geographical references

Looking at the history of the Transylvanian Saxons, one can comprehend the gradual identity change starting from the $18^{\text {th }}$ century onwards as strictly linked with a territorial issue. Together with this identity change, symbolic geographies were also bound to change. Commenting upon Erwin Wittstock's introduction to Königsboden, a collection of stories, historian Krista Zach (1992) noticed how the term Königsboden was used in order to convey a message regarding Transylvanian Saxon identity traits. Without actually naming the group, Wittstock (1941: 5-7) described a collective subsumed to Königsboden, the territory becoming a symbol for group identity.

The importance granted to spatiality is visible in both Zillich's and Meschendörfer's works, from the very titles. Zillich wrote a novel set somewhere "between borders and eras". Meschendörfer wrote a novel about the town in the East. The spatial choices are never random: Zillich would follow his characters from Kronstadt to the Italian Alps, where he did indeed fight during the First World War in the ranks of the Habsburg Army. At some points, the characters did cross the Carpathians in order to go to Wallachia. These trips and the characters' impressions of them have a definite exotic allure, hence the possibility to speak of a specific Orientalizing gaze of Transylvanian Saxons over the Romanians, especially over the ones on the other side of the mountains. Meschendörfer would have his characters travel from Kronstadt to classical Greece, in a trip where they enter in contact with the cultural grandeur and luxury of cultural Europe, but also to Strasbourg or Munich, where young Transylvanian Saxons attend universities. Scherg, on the contrary, did not have his characters go further than Klausenburg (Cluj) and even then, the Hungarian aristocrat was the one having a tight relationship with the town. In the context of Transylvanian Saxon literature Schlattner is the most daring: Das Klavier im Nebel, his last novel, is in a way the depiction of a road trip passing more or less through the entire Romania: his characters visit Romanian lieux de mémoire such as Curtea de Argeș or cities such as Bucharest and Constanţa. ${ }^{6}$

The territorial setting of the literary works under scrutiny is not random, and it tells a lot about Transylvanian Saxon symbolic geographies during different periods of time. Zillich and Meschendörfer, völkisch writers from the interwar period, were witnessing the passage to a Transylvania administered by Romanians, yet their cultural and geographical references were rarely 'Romanian'. In Meschendörfer's symbolic geography, Kronstadt was definitely closer to Munich or Strasbourg. The constant cultural communication with the German-speaking space ensured that Transylvanian Saxon symbolic geography was confined neither to the Transylvanian region, nor to the wider Romanian state. Zillich did grant some more attention to the world beyond the Carpathians, yet Lutz, the biographical alter-ego of the author, is innocently saying to his Romanian friend: "The ones behind the mountains - what do we care about them!?" (Zillich 1937: 52). The world on the other side of the Carpathians is a sort of terra incognita, sometimes exotic and appealing; yet it is also the place

6. In Northern Dobrudja, the only region of Romania, that was stricto sensu part of the Ottoman Empire. Turkish and Tartar minorities still live there. 
where women become prostitutes, such as Lydi Strnicek (Zillich 1937: 547). ${ }^{7}$ In the cases of Zillich and Meschendörfer, identity discourses and symbolic geographies are conveying the message of Transylvanian Saxons as civilizing colonizers and defenders of Europeanness, in a rather inferior environment, that in the long run aims at their assimilation. The cultural connections with Germany and the German-speaking space are a way of enhancing a specific type of symbolic geographies, reinforcing the typical positive stereotypes associated with Saxonness. Furthermore, the readership of both Meschendörfer and Zillich was almost exclusively German, from both Romania and Germany. Their works have not been translated in Romanian at the time, and they were present on the German cultural market during the National-Socialist period. Zillich settled down in Germany and continued to be an advocate of a Nazi-oriented understanding of Germanness even after the Second World War, being also directly involved at the highest level in the Homeland Association (Landsmannschaft) of Transylanian Saxons in Germany.

The end of the Second World War and the fall of Communism brought forth a reevaluation of Transylvanian Saxon symbolic geographies. Decoupling them from the centuries-old cultural connections with the German-speaking space ${ }^{8}$, the Romanian state directly and indirectly pushed towards the formation of a rumäniendeutsche (Romanian-German) identity, attempting to merge together Transylvanian Saxons and the other German-speaking groups in the country, such as Banat Swabians. The discursive creation of such an identity is visible within literary circles from the 1960s onwards, as Annemarie Weber (2010) showed in her latest book. The strong connections between the literary world and identification discourses have been constant in Transylvanian Saxon history, the Communist era constituting no exception. Scherg wrote in this context, so the cultural horizon of his Transylvanian Saxon symbolic geographies was bound to be much more limited. He was thus envisaging the integration of another stereotypical aspect of Transylvanian Saxon identity, das Zusammenhalten (holding together), into a new identity model, the harmonious socialist one, the latter enjoying symbolical leverage upon the former. The main character in his book, Peter Merthes, is a coachman, living in harsh conditions and striving to build a better life for him and his family. He is a Socialist without knowing it, thus conveying the idea of Transylvanian Saxons as prone to appropriate the Communist message, eventually post-national.

Schlattner, writing after the fall of Communism, seems to have appropriated a sort of rumäniendeutsche specificity: his objective is to describe a world that would otherwise fall into oblivion, due to the large Transylvanian Saxon migration to Germany. His perspective on the Romanian state's treatment of minorities in general and of the German minority in particular is rather positive. In his Transylvanian Saxon symbolic geography, the positive group stereotypes are still present, yet the

7. Hamlin (2010) also remarks that during the First World War, women in Romania were represented by Germans (from the Reich) as sexually promiscuous.

8. Of course, there was the GDR, yet interestingly enough the German communist state was never properly perceived as a potential cultural homeland for Transylvanian Saxons, unlike the Federal Republic of Germany and even Austria on a more limited scale. See Koranyi 2008. 
attention granted to the other ethnic groups shows a wider openness. Schlattner is a conscious member of a minority, he shows no nostalgia after the privileged medieval past, whilst advocating a particular Romanian 'multicultural model': the Eastern character of the country becomes a virtue, and Transylvanian Saxons are (were) part and parcel of this model. Despite what seem to be in his perspective mere accidents of history, such as the Nazification of the Saxon community, the Second World War, and the Jewish persecutions, his Transylvania is something of a Transilvania felix. For him, Transylvanian Saxons are indeed Romanian German, and in his symbolic geography, he is integrating them into the Romanian cultural and social landscape, together with the other minorities (Hungarians, Jews, Armenians, Gypsies etc.). In Der geköpfte Hahn, the Saxon priest and his wife have to host two Germans from the Reich. In this context, they purposefully provide them with a "Turkish breakfast", i.e. "Turkish coffee, Turkish palukes - also called rachat or racahout -, sherbet, and halvah, everything seeped in from Turkey. We wanted to present our guests from the Reich something from the Balkans..." (Schlattner 2009: 331).

Of course, in Schlattner's novel, one finds a multitude of voices and characters, as he is exquisitely depicting a series of social phenomena typical of the Transylvanian Saxon community after 1918. Yet it is not difficult to see that he is extremely well disposed to Romanian things, at the same time integrating Transylvanian Saxon history into Romanian history. He also does that in non-literary settings, where he speaks for example of "Romania, his homeland, who allowed - or, even more, who facilitated me to remain German". ${ }^{9}$ This statement is interesting, as it takes into account the mass migration of Germans from Romania, one of whose reasons was the perception of Romanian policies as assimilationist and leading to the loss of identity. For Schlattner, Transylvanian Saxon heritage contributes to Romania's Europeanness, but at the same time he does not dismiss the 'Eastern' character of the Romanian environment. The positive Saxon stereotypes are thus integrated into specific contemporary Europeanizing identity discourses, such as the discourse on multiculturalism, Saxons becoming more of a 'bridge' between cultures, as opposed to the older 'Occidental outpost' type of representation.

\section{East and West}

For the writers of the interwar period, raised and educated in the Transylvanian Saxon community before 1918, Europe has to be perceived according to the German role and influence in its development. The transition to Romania is seen as a transition towards the East: "Here, the West was reigning: security, law and Heimat. Now, the unknown East is coming. Now, we have become something completely novel, we have become Germans from abroad. Do understand that! We are sitting in a centuriesold German tower and the unknown life is flowing outside" (Zillich 1937: 604). Romania was therefore the East, coming to lay its grip on the Western type of life in Transylvania.

9. http://www.primariarosia-sb.ro/rosia-eginald-norbert-schlattner--205.html (last accessed, 22 January 2012). 
Zillich dealt extensively with cultural-geographic issues in his Zwischen Grenzen und Zeiten, and he did that by discursively reproducing the symbolic division between East and West. One of the characters in Zillich's novel is making an excurse through Hungarian history, connecting Hungary's Europeanness with the summoning of German settlers, able to bring the "radiant Occidental civilisation" (Zillich 1937: 202). Moreover, the reader finds here a black on white circumscription of Europe as a cultural space: "We have come to this country to defend the borders. Whose borders? Europe's borders." (Zillich 1937: 202). Further on in the novel, the same character speaks about the border in the vicinity of Kronstadt, as being "the border to another world" (Zillich 1937: 298). The Romanian state was therefore perceived as another world and when the Romanian armies occupied Kronstadt during the First World War, three quarters of the Saxon population left the town. Not only that the Romanians appointed a new Romanian mayor, not only there were no German and Hungarian texts of the authorities' decisions, but also not even the Black Church bells tolled anymore (Zillich 1937: 415). All the four novels deal with the Saxon loss of Kronstadt, both on a symbolic and a literal level. It signifies the melting into another world, un-Western, un-European (Meschendörfer, also Zillich), it announces the future Communist (Romanian) takeover (Scherg), it symbolizes the eventual integration of Saxonness in Romania (Schlattner).

In the novels of both Meschendörfer and Schlattner, the description of the popular feast called "Junii Braşovului" (Braşov's Youngsters) is highly relevant, since it shows the tensions existing between the Romanian and the German populations in the town. Spiridon (2002: 93) already remarked and commented upon the intertextual character of Schlattner's reference to the feast. The narrator in Die Stadt im Osten, an alter ego of the author, is fascinated by the festivity, yet at the same time emblematically frightened. Traditionally, the feast marked a day in the year when the Romanian population, normally not allowed to inhabit within the walled town of Kronstadt, came to the walls of the town, in a ritual celebrating youthfulness and power. At the same time, the festivity marked a symbolical appropriation of power over the town, gaining in time a sort of foretelling relevance. Meschendörfer notes rhetorically: "And if the monstrous of the old legend would happen to happen once! If the Romanian riders succeeded to enter the inner town and to circle three times the old Saxon town hall, then the city would belong to them!" (Meschendörfer 1931: 293). He is bewildered by the Romanian costumes, "a piece of rampant folk phantasy", as the "coloured Orient is gleaming from each of them" (Meschendörfer 1931: 294). The contrast to the often mentioned black attire of the Saxon officials in the Black Church is striking, marking the dichotomy West-East as a dichotomy of sober rationalism and seriousness (Lutheranism) and Oriental colours.

If one looks at Meschendörfer's account of the festivity and compares it to Schlattner's account, one can comprehend the identity changes I was alluding to when laying down the scope of this paper. Schlattner's character witnesses the "Junii Braşovului" festivities when the town was already part of Romania. Although at first glance largely inhabited by Germans, as the numerous flags displayed in downtown Kronstadt suggest, the Romanian population, through the aforementioned celebration, 
would claim their right to the centre of the town and at the same time would quietly and almost unnoticingly lay their grip on it.

As Adrian Lăcătuș (2009: 73-79) noticed, the Romanians are almost absent from Meschendörfer's novel, although it is set at the end of the $19^{\text {th }}$ century and the beginning of the $20^{\text {th }}$ century. Demographically, the percentage of the Romanian population during that time was already worrying for the Saxons, as Meschendörfer is indeed suggesting. Yet none of the characters in the novel is Romanian, as these are only exotic and marginal figures, who at the same time threaten the Transylvanian Saxon high culture and civilization of Kronstadt. The author is writing from the position of a representative of an "island" of culture in the East, an idea also dear to other Transylvanian Saxon authors. The last pages of the 1931 edition, severely censored in the Romanian translation from the 1980s, offer the perspective of a Transylvanian Saxon self-victimization, under the influence of the unfulfilled promises from the Declaration of Alba-Iulia in 1918. The "world powers" are accused of forgetting this Transylvanian Saxon island, striving to cope with the threats coming from the Romanian authorities. The Saxons as seen by Meschendörfer are in peril: after almost 400 pages in which Romanians are barely present, the writer is strongly deploring the fate of the Transylvanian Saxon minority in the newly enlarged Romanian state. All they want is to "remain German" (Meschendörfer 1931: 371) - if not, "may the storm flood take us all". Conveyors of culture in the East, the Saxons are about to lose their identity because of the East. In Meschendörfer's geography, the East exists, Kronstadt is a town in the East, and it is the geographical location of Kronstadt that makes it so easily penetrable.

Zillich approached the same subject, yet he did it some years later, publishing Zwischen Grenzen und Zeiten after he had already settled down in Germany. Lutz, the main character of the novel, and at the same time an alter ego of the author if one looks at the biographical aspects, concludes towards the end of the work that the fate of Europe and of the German people is drawn in the East (Zillich 1937: 641). The relationship of the Transylvanian Saxons with the East is unilateral in some ways, as the former have given to the latter much more than they have received, in Lutz's (Zillich's) vision.

Only Scherg, in his Da keiner Herr und keiner Knecht, did not look at questions related to East and West within Transylvanian Saxon identity. The world of his characters is, from a spatial/territorial point of view, much more condensed. In the background, one can understand the attempt to mitigate the high-profiled aims of Communist ideology in Romania at the end of the 1950s and beginning of the 1960s with Transylvanian Saxon self-consciousness. This might also be one of the reasons for which Scherg chose an outsider as the main character of his novel, a not-so-typical phenomenon in traditional Transylvanian Saxon literature, which usually deals first with the community and then with the individual (Spiridon 2002: 66). In this specific case, this shows, beyond a literary left-oriented propensity for the life of the Dostoevskian "humiliated and insulted", a closure in itself of the Transylvanian Saxon world, taking place during Communism.

Looking at the works of Zillich, Meschendörfer, and Schlattner some almost 70 years later, one sees that the positive stereotypes associated with Saxonness by the 
elites of this group have not changed substantially. Nonetheless, modifications can be discerned, namely in the wider discursive framework wherein they are integrated. For Zillich and Meschendörfer, völkisch writers from the interwar period, Transylvanian Saxon symbolic geographies are strongly connected with the Europeanness of Germanness. Saxons act therefore as educators of lesser people who on the long run turn out to be ungrateful, as they do not recognize the Saxon superiority. Saxons are an island of civilization, within what is actually a mobile geography: Transylvanian Saxon self-identification, as professed by the two writers, is not always the same. Through the voices of their characters and through their discourses (in the case of Zillich, doubled by subsequent politically involved discourses and actions as well), the writers promote an ambiguous image: either Transylvanian Saxons stand for the West and by means of an interesting metonymy, the whole of the region they colonized (Transylvania, and by extension the entire Hungarian kingdom) becomes West, i.e. Europe, or, differently, Saxons are indeed colonizers meant to convey high culture and civilization to the uncultured East, i.e. to the Romanians, but who end up in peril of being suffocated by the East and thus losing their identity. The latter type of discourse is, of course, the more conflictual one, yet both of them can be theoretically substantiated through the recourse to the 'nesting orientalisms' framework.

The Eastern other is in both cases more 'Oriental' or, even more directly, more 'Balkanic'. The symbolic border lying in Burzenland and dividing Transylvania from the Ottoman-influenced Romanian principalities plays a key role for both writers and for their characters as the Romanian world beyond the mountains is, in both cases, a different one, of little interest until 1918. However, this world is slowly catching hold of the Saxons and pressuring them into assimilation or, in other words, transforming high culture into confusion and un-culture. Erasing the symbolic Carpathian border, a political event following the annulment of the physical Königsboden border during the Habsburg reign in Transylvania, brought with it, for Meschendörfer and Zillich, a decoupling from the political and cultural world whose orbits were Vienna or Berlin, hence the "we-discourses" emphasizing the "island" type of feeling, i.e. alienation and an identity in peril.

However, Schlattner's work suggests a different approach. The voices of his characters are embodying a wide range of opinions on Transylvanian Saxon identity and, per force, on Balkanism and Orientalism. Yet the cultural memory character of Schlattner's work is visible in the sense that it reconstructs a past through the construction of a discourse. In this discourse the positive Saxon stereotypes are still present, yet the way the ethnic and cultural environment is perceived is different. The positive disposal to Romania will be even more visible in Schlattner's last novel, Das Klavier im Nebel. Of course, some of the characters in the book are echoing the views of Transylvanian Saxon elites such as in Zillich's and Meschendörfer's works. However, the narrator shows at the same time much more attention to the other ethnicities in Transylvania and does not present them in the schematized manner of a Zillich or Scherg. He moves in a multiethnic world, he acknowledges its multicultural character, he praises it, but the hierarchical view of the various ethnies in Transylvania is not present anymore. Schlattner appropriated the idea of a Romanian-German identity and, letting aside the contextual reformulations of past identifications, he seems 
to convey the message of a 'European' Romania, a grosso modo tolerant country, which lets its German minority live and develop its identity. The 'Oriental'/'Balkan' Romania exists in the minds of the older characters, but the young Felix does not end up appropriating these dichotomies. Clement, the main character in Das Klavier im Nebel, Schlattner's latest work, will directly reject them.

\section{Conclusions}

In this article, I have attempted to show the subtle changes involving Transylvanian Saxon identity and symbolic geographies by looking at specific literary products, written between 1918 and 2008. Considering concepts such as 'nesting orientalisms' or 'Euro-Orientalism', I showed that positive Transylvanian Saxon self-stereotypes, and their appending view of the world beyond the Carpathians, witnessed a subtle formal change from 1918 onwards, very much depending on the time of their employing. Meschendörfer and Zillich, völkisch writers from the interwar period, used them in order to convey the vision of a civilizing German people, endangered in an alien, Eastern environment, whereas more recently Schlattner has used them in order to disseminate an image of multiculturalism, a sort of Balkanic/Eastern surplus value of Germanness. In-between these two poles, Scherg, writing under the Communist regime, tried to show a Transylvanian world more territorially closed in itself, without granting attention to issues related to East and West.

Just like identities, symbolic geographies are mobile and fluctuating and the Transylvanian Saxon case bears proof for that. At the same time, we can definitely speak of a strong core of identities and symbolic geographies, as the persistence in time of specific positive stereotypes associated with Saxonness and/or of Saxon representations of otherness shows. However, without changing too much, such images have been used differently, hence the possibility that symbolic geographies, just like identities and representations of otherness, be used and re-used, according to contextual needs and contextual discourses. Last, but not least, the presence (or the absence) of symbolic geographies (in this case, of representations of Balkans and of the neighbouring other) is strongly connected with the issue of politics, understood in its broadest meaning, as, once again, the Transylvanian Saxon case shows. "East" and "West" become mobile concepts, endowed with different traits depending on a series of contextual causes. Looking at identity politics and identification discourses from a perspective focusing on symbolic geographies enables situating the former in a broader context. Symbolic geographies do not turn into a concept supplanting the analytical necessity of other alike concepts such as "identity politics" or "identification discourses", yet joins them, emphasizing a specific dimension within the study of the latter.

\section{Acknowledgments}

The author would like to thank Georg Aescht, Sacha Davis, and the two anonymous reviewers for their suggestions. A version of this paper was presented at "Remaking Borders", the first EastBordNet conference, taking place in Catania (20-22 January 2011). 


\section{References}

Adamovsky, Ezequiel, 2005. "Euro-Orientalism and the Making of the Concept of Eastern Europe in France, 1810-1880”, The Journal of Modern History, 77(3): 591-628.

Antohi, Sorin, 1999. “Cioran și stigmatul românesc. Mecanisme identitare și definiții radicale ale etnicității”, Civitas imaginalis. Istorie și utopie în cultura română, second edition: 239-324. Iassy: Polirom.

BakiĆ-Hayden, Milica, 1995. "Nesting Orientalisms: The Case of Former Yugoslavia”, Slavic Review, 54(4): 917-931.

Bakić-Hayden, Milica and Robert M. Hayden, 1992. “Orientalist Variations on the Theme 'Balkans': Symbolic Geography in Recent Yugoslav Cultural Politics”, Slavic Review, 51(1): 1-15.

BJELIĆ, Dušan I., 2002. "Introduction: Blowing Up the 'Bridge'”, in Dušan I. Bjelić and Obrad Savić (eds.), Balkan as Metaphor. Between Globalization and Fragmentation: 1-22. Cambridge, MS and London: MIT Press.

BoiA, Lucian, 2001. Romania: borderland of Europe, transl. by James Christian Brown. London: Reaktion Books.

Cercel, Cristian, 2011. "The Relationship between Religious and National Identity in the Case of Transylvanian Saxons (1933-1944)”, Nationalities Papers, 39(2): 161-180.

Custred, Glynn, 1991. "Dual Ethnic Identity of the Transylvanian Saxons", East European Quarterly, 25(4): 483-491.

DAVIS, Sacha, 2011. "East-West Discourses in Transylvania: Transitional Erdély, German-Western Siebenbürgen or Latin-Western Ardeal?", in Alexander Maxwell (ed.), The East-West Discourse. Symbolic Geography and its Consequences. Bern: Peter Lang.

Evans, R. J. W., 2006. "Transylvanian Saxons", in Austria, Hungary and the Habsburgs. Essays on Central Europe, c. 1683-1867: 209-227. Oxford: Oxford University Press.

Grama-Neamțu, Emanuela, 2010. "Building Politics, Searching for Heritage: Archeology, Architecture, and Imageries of Social Order in Romania (1945-2007)", PhD Thesis, Ann Arbor, University of Michigan.

GüNDISCH, Konrad (with the collaboration of Matthias Beer), 1991. Siebenbürgen und die Siebenbürger Sachsen. Munich: Langen Müller.

Gündisch, Konrad, Wolfgang HöPken and Michael Markel (eds.), 1998. Das Bild des Anderen in Siebenbürgen. Cologne, Weimar, Vienna: Böhlau Verlag.

Hamlin, David D., 2010. "“Wo sind wir?' Orientalism, Gender and War in the German Encounter with Romania”, German History, 28(4): 424-452.

Higounet, Charles, 1989. Les Allemands en Europe Centrale et Orientale au Moyen Age. Paris: Aubier.

Koranyi, James, 2008. "Between East and West: Romanian German Identities since 1945”, PhD Thesis, University of Exeter.

LĂCĂTuș, Adrian, 2009. "Tradiție, autonomie și realizare de sine în Die Stadt im Osten de Adolf Meschendörfer", in Modernitatea conservatoare: aspecte ale culturii Europei Centrale: 73-79. Braşov: Editura Universității "Transilvania”.

Liulevicius, Vejas Gabriel, 2009. The German Myth of the East: 1800 to the Present. Oxford: Oxford University Press.

Livezeanu, Irina, 1995. Cultural Politics in Greater Romania: Regionalism, Nation Building and Ethnic Struggle, 1918-1930. Ithaca and London: Cornell University Press.

Meschendörfer, Adolf, 1931. Die Stadt im Osten. Sibiu: Verlag Krafft \& Drotleff. 
Mitu, Sorin, 2007. Europa Centrală, Răsăritul, Balcanii: geografii simbolice comparate. Cluj: International Book Access.

Motzan, Peter, 1997. "Die deutschen Regionalliteraturen in Rumänien (1918-1944). Forschungswege und Forschungsergebnisse der Nachkriegszeit", in Peter Motzan and Stefan Sienerth, Deutsche Regionalliteraturen in Rumänien: 1918-1944, 33-67. Munich: Verlag Südostdeutsches Kulturwerk.

—, 2001. "Dingsymbol kollektiver Identität. Die Schwarze Kirche als 'Gegenstand' der siebenbürgischdeutschen Literatur (1919-1944)”, in 50 Jahre Südostdeutsches Kulturwerk - Südostdeutsche Vierteljahresblätter 1951-2001: 55-64. Munich: Südostdeutsches Kulturwerk.

Motzan, Peter, Möckel, Andreas, 1994. "Kleinsächsisch oder Alldeutsch? Zum Selbstverständnis der Siebenbürger Sachsen von 1867 bis 1933”, in Walter König (ed.), Siebenbürgen zwischen den beiden Weltkriegen: 129-141. Cologne, Weimar, Vienna: Böhlau Verlag.

Motzan, Peter and Stefan Sienerth (eds.), 1997. Deutsche Regionalliteraturen in Rumänien: 1918-1944. Munich: Verlag Südostdeutsches Kulturwerk.

NÄGLER, Thomas, 1992. Die Ansiedlung der Siebenbürger Sachsen. Bucharest: Kriterion Verlag.

Neubauer, John and Marcel Cornis-Pope (with Sándor Kibédi-Varga and Nicolae Harsanyi), 2006. “Transylvania's Literary Cultures: Rivalry and Interaction”, in Marcel Cornis-Pope and John Neubauer (eds.), History of the Literary Cultures of East-Central Europe: Junctures and Disjunctures in the 19th and 20th Centuries, vol. II: 245-282. Amsterdam and Philadelphia: Johns Benjamins Publishing.

PhilipPI, Paul, 1994. "Nation und Nationalgefühl der Siebenbürger Sachsen”, in Hans Rothe (ed.), Die Siebenbürger Sachsen in der Geschichte und Gegenwart, pp. 69-86. Cologne, Weimar, Vienna: Böhlau Verlag.

Rотн, Harald, 1996. Kleine Geschichte Siebenbürgens. Cologne, Weimar, Vienna: Böhlau Verlag.

-, 1998. “Autostereotype als Identifikationsmuster. Zum Selbstbild der Siebenbürger Sachsen”, in Gündisch, Höpken and Markel (eds.): Das Bild des Anderen in Siebenbürgen, 178-191. Cologne, Weimar, Vienna: Böhlau Verlag.

Schlattner, Eginald, 2007. Das Klavier im Nebel. Munich: Deutscher Taschenbuchverlag.

-, 2009. Der geköpfte Hahn, 6th ed. Munich: Deutscher Taschenbuchverlag.

Sienerth, Stefan, 2003. "Adolf Meschendörfer und Heinrich Zillich im Literaturbetrieb des 'Dritten Reiches", in Michael Markel and Peter Motzan (eds.), Deutsche Literatur in Rumänien und das Dritte Reich: Vereinnahmung - Verstrickung - Ausgrenzung: 83-118. Munich: IKGS Verlag.

SPIRIDON, Olivia, 2002. Untersuchungen zur rumäniendeutschen Erzählliteratur der Nachkriegszeit. Oldenburg: Igel Verlag.

Teutsch, Fr., 1916. Die Siebenbürger Sachsen in Vergangenheit und Gegenwart. Leipzig: K. F. Koehler.

-, 1924. Die Siebenbürger Sachsen in Vergangenheit und Gegenwart, 2nd augmented edition. Sibiu: Wilhelm Krafft Verlag.

Weber, Annemarie, 2010. Rumäniendeutsche? Diskurse zur Gruppenidentität einer Minderheit (19441971). Cologne, Weimar, Vienna: Böhlau Verlag.

WedEKIND, Michael. 2004. "Der siebenbürgische Karpatenverein (1880-1944). Ein Beitrag zur Sozialgeschichte Siebenbürgens", Amnis. Revue de civilisation contemporaine Europe/Ameriques 1(2004). Available at http://amnis.revues.org/1088.

Wiтtsтоск, Erwin, 1941. Königsboden. Erzählungen. Munich: Albert Langen-Georg Müller.

ZACH, Krista, 1992. “"Wir wohnten auf dem Königsboden...». Identitätsbildung bei den Siebenbürger Sachsen im historischen Wandel", in Gerhard Seewann (ed.), Minderheitenfragen in Südosteuropa. Beiträge der Internationalen Konferenz "The Minority Question in International 
Perspective 1900-1990, Inter University Center, Dubrovnik, 8.-14. April 1991, 115-137. Munich: Südostdeutsches Kulturwerk.

-, 1998. "Religiöse Toleranz und Stereotypenbildung in einer multikulturellen Region. Volkskirchen in Siebenbürgen”, in Gündisch, Höpken and Markel, (eds.). Das Bild des Anderen in Siebenbürgen, 109-154. Cologne, Weimar, Vienna: Böhlau Verlag.

Zillich, Heinrich, 1937. Zwischen Grenzen und Zeiten. Munich: Albert Langen-Georg Müller.

Zimmermann, Harald, 2000. Der Deutsche Orden im Burzenland: eine diplomatische Untersuchung. Cologne, Weimar, Vienna: Böhlau Verlag. 